\title{
Correction to: Video sequence feature extraction and segmentation using likelihood regression model
}

\section{B. Satheesh Kumar ${ }^{1} \cdot$ K. Seetharaman ${ }^{2}$}

Published online: 5 May 2021

(C) Springer Science+Business Media, LLC, part of Springer Nature 2021

\section{Correction to: Multimedia Tools and Applications (2021) https://doi.org/10.1007/s11042-021-10829-9}

On pages 3, 4, 8, 9 and 11 of the original publication contain some casing, spelling and formatting mistakes. The original article has been corrected.

Publisher's note Springer Nature remains neutral with regard to jurisdictional claims in published maps and institutional affiliations.

The online version of the original article can be found at https://doi.org/10.1007/s11042-021-10829-9

B. Satheesh Kumar vbsatheesh30@gmail.com

K. Seetharaman kseethaddeau@gmail.com

1 Department of Computer Science and Engineering, Annamalai University, Annamalai Nagar, TamilNadu, India

2 Department of Computer and Information Science, Annamalai University, Annamalai Nagar, TamilNadu, India 